Viti i XII I ${ }^{\text {te }}$ i Botimit, Nr.1-2,

Dhjetor 2020

\title{
ROLI I SHËRBIMIT PSIKOLOGJIK NË MENAXHIMIN E ÇRREGULLIMIT TË STRESIT PANDEMIK DHE RUAJTJEN E MIRËQENIES EMOCIONALE GJATË PERIUDHËS SË COVID-19.
}

\author{
Elisabeta Kafia,* Silva Ibrahimi* \\ *Department i Psikologjisë, Albanian University,Tirana, \\ Adresë kontakti : elisabetakafia@yahoo.co.uk
}

\section{Përmbledhje}

Fokusi i këtij artikulli është të propozojë një psikopatologji të re: Çrregullimin e Stresit Pandemik. Objektivi tjetër është të shfaqë një pikëpamje të gjerë dhe mbështetëse të asocimeve, sfidave dhe strategjive të përballimit psikologjik ndaj Covid-19 me fokus në masat e prevenimit psikik dhe jo vetëm social. Sot shihet një shtim i besimeve patogjenike të lidhura me virusin, frika dhe paniku te specialistët e shëndetit dhe grup-moshat e ndryshme që mund të preken nga virusi. Informacionet e përditësuara mbi mutacionet e virusit shtojnë edhe më tepër shtresat e gjendjeve emocionale negative të akumuluara. Në komorbiditet me vetë stresin pandemik dhe me çrregullimet e tjera, këto qendrime patogjenike e vënë në pikëpyetje stabilitetin psiko-emocional dhe sjelljen e shëndetshme sociale të individit.

Sot, individët-pacientë të frikësuar nga Covid-19 jo vetëm luftojnë për rritjen e sigurisë së tyre por edhe me shtimin e mendimit supersticioz, ashpërsinë dhe kompleksitetin e sëmundjes me komorbiditete të tjera, që ulin nivelin e mirëqenies psikologjike . Për të përballuar në mënyrë të suksesshme këto sfida, është e domosdoshme të ri-përcaktohet roli i Psikologut të shëndetit dhe i të gjitha figurave shëndetësore në komunitet, si për studimin e dukurisë, zhvillimit, faktorëve dhe pasojave, ashtu edhe në psikoedukimin për menaxhim të ankthit e panikut dhe në trajtim profesional të personit me Çrregullim të Stresit Pandemik (traumatik).

Fjalë çelës: covid-19, çrregullim i stresit pandemik, prevenim psikik, mirëqenie e shëndetit mendor 
Elisabeta Kafia, Silva Ibrahimi

\title{
The Role of Psychological Service in Pandemic Stress Disorder and the Preservation of Emotional Welfare during Covid-19.
}

\begin{abstract}
The focus of this article is to propose a new psychopathology: Pandemic Stress Disorder. Another objective is to present a broad and supportive view of associations, challenges and psychological coping strategies against Covid-19 with a focus on psychic prevention measures and not just social. Today there is an increase in pathogenic beliefs associated with the virus, fear and panic among health professionals and different age groups that may be affected by the virus. Updated information on virus mutations adds even more layers of accumulated negative emotional states. In comorbidity with pandemic stress itself and other disorders, these pathogenic attitudes call into question the psycho-emotional stability and healthy social behavior of the individual.

Today, individual-patients intimidated by Covid-19 not only increase their efforts to safety but also fight with increase of superstitious thinking, severity and complexity of the disease with other comorbidities, which reduce the level of psychological well-being. To successfully meet these challenges, it is necessary to redefine the role of the health Psychologist and all health figures in the community, both for the study of the phenomenon, development, factors and consequences, and in psychoeducation for the management of panic anxiety and in the professional treatment of the person with Pandemic (Traumatic) Stress Disorder.
\end{abstract}

Keywords: covid-19, pandemic stress disorder, psychic prevention, mental health well-being

\section{Hyrje}

Jetesa, në kohën e kësaj pandemie globale ka zhvilluar një sërë formash të menaxhimit individual në luftën për ruajtjen e mirëqenies personale ne prani te virusit/ose covid-19. Teksa distanca fizike ndihmon në parandalimin e shpërhapjes së virusit biologjik, distancimi social mund të shkatërrojë të gjitha përpjekjet për mbajtjen e mirëqenies psiko-sociale! Është e domosdoshme që të ngadalësojmë shpërhapjen e Covid-19 por, njëkohësisht, gjatë kësaj periudhe traumatike duhet të qendrojmë të lidhur me njëri-tjetrin. Është e nevojshme kësisoj mbajtja e lidhjes sociale, e konsideruar nje lloj mbrojtje. Në përpjekjet e tyre për të kuptuar identitetin njerëzor dhe zhvillimin psikik, specialistët kanë mbajtur pozicione dhe qasje të ndryshme.

Argumentat e tyre variojnë nga pikëpamjet e thjeshta intra-psikike dhe makro-sociale në 
ROLI I SHËRBIMIT PSIKOLOGJIK NË MENAXHIMIN E ÇRREGULLIMIT TË STRESIT PANDEMIK DHE RUAJTJEN E MIRËQENIES EMOCIONALE GJATË PERIUDHËS SË COVID-19.

identifikimin e proceseve dhe terminologjive të lidhura me to (1). Hulumtimet për një gjendje të ekuilibruar të identitetit përbëjnë një nga qasjet thelbësore të studimeve mbi personalitetin e njeriut në tri dekadat e fundit (2). Burimet e mëdha të identitetit variojnë në nivelin e rëndësisë së tyre: burimet më të qarta qëndrojnë në sjelljen dhe qendrimin e individit ndërsa ato me më pak të qarta fokusohen ne tiparet e personalitetit tonë. Fleksibiliteti dhe funksioni i përshtatjes të personalitetit normal reflekton natyrën e mekanizmave mbrojtëse të një personaliteti të shëndetshëm dhe të maturuar.Kur ndodh një ngjarje traumatike,këto struktura përshtatëse të personalitetit bëhen vulnerabël dhe individi e sheh veten të pambrojtur.Frika dhe ankthi, të shtuara me gjendjen e stresit të vazhdueshëm krijojnë një psikogjenezë me tendencë traumatike. Zhvillohet kështu një prototip personaliteti (tipar) që përforcon qenien e këtij individi në një gjendje të çrregullimit traumatik të vazhduar. Individët mund të jenë asimptomatikë,sikundër në rastin e ngjarjes stresante,d.m.th. virusit,por ato mund të akumulojnë strese dhe i represojnë ato kur përkeqësohen. Simptomat e represuara të një traume të lehtë të panjohur krijojnë një tendencë të lartë për përjetimin e ngjarjes stresante në personalitetet anksioze dhe me tipare të frikës të shtuar.

Në referencë të artikujve të rinj shkencorë të lidhur me Covid-19, shkencëtarët kanë hasur disa aspekte sfiduese. Në artikullin e tyre të përbashkët autorët(3) argumentojnë se teksa studiohet shpërndarja e drejtë e burimeve mjekësore dhe vaksinave për të menaxhuar pandeminë e Covid-19, studiuesit duhet të jenë të vetëdijshëm për disa parime etike në lidhje me popullatat dhe komunitetet ku ato do të shpërndahen si: maksimalizimi i përfitimeve; dhënia e prioritetit punonjësve shëndetsorë/te shendetit; mos shpërndarja e këtyre burimeve mbrojtëse vetëm të depistuarve të parë; përmbajtja nga gjykimet personale për një komunitet a një tjetër; të qenurit reaktiv ndaj evidencave; njohja e pjesëmarrjes në kërkime dhe aplikime i të njëjtave parimeve ndaj pacientëve mbartës dhe jo-mbartës të virusit. Sipas autorëve,konsiderohet një pikë thelbësore e trajtimit, që shkencëtarët të jenë të vetëdijshëm dhe të respektojnë të gjitha parimet etike të komunikimit në Covid-19 si e drejtë themelore e shëndetit të pacientëve. Por,qenia në një situatë pandemike mund të lindë edhe çështje të lidhura me prioritetin e kujdesit:cili duhet trajtuar i pari dhe si mund të menaxhojnë punonjësit shëndetsorë /e shëndetësisë protokolle të drejta trajtimi për të gjithë kur ndeshen me mungesë të pajisjeve mjeksore dhe ne terren te ne paniku në rang kombëtar? I njëjti artikull kërkimor, në këtë pikë sugjeron qe, prioriteti në rastet e burimeve të kufizuara si për vaksinat duhet të ketë për qëllim edhe shpëtimin e sa më shumë jetëve që të jetë e mundur edhe maksimalizimin e trajtimeve të çrregullimet të stresit pandemik te individët në njësinë e kohës. Shpëtimi i sa më shumë jetëve dhe viteve në jetë është një pranim konsensual nga të 
Elisabeta Kafia, Silva Ibrahimi

gjithë ekspertët $(4 ; 5 ; 6 ; 7 ; 8)$.

Pasojat e Covid-19, sipas autorëve, kanë qenë jashtëzakonisht më të këqija te grupet vulnerabël të qendrave komunitare, te të moshuarit dhe personat me sëmundje kronike dhe sëmundje të tjera shëndetesore (9). Andaj, dhënia e prioritetit ndaj personave të këtyre kategorive për marrjen e vaksinës, mund të jetë e justifikueshme pasi vaksinat në vetvete shërbejnë për të parandaluar dhe jo për të kuruar. E njëjta formulë logjike qendron edhe për trajtimin psikologjik në pandemitë masive. Ne parandalojmë përkeqësimin e gjendjes mendore duke u dhënë përparësi atyre që shfaqin prototip të personalitetit me rrezik të lartë dhe jo vetëm atyre që dyshohet se mund të kenë këtë prototip personaliteti për të zhvilluar stresin pandemik. Sjellja njerëzore ndikohet dhe nxitet nga dëshira për marrëdhënie ndërpersonale dhe ndërveprim njerëzor. Jetesa, në një botë kufizimesh dhe frike pandemike shton forcën e patologjive psikike te personalitetet me tendencë psikopatologjike dhe dëmton progresivisht shëndetin e tyre mendor.

\section{Çrregullimi i Stresit Pandemik dhe Prototipi i Çrregullimit Traumatik.}

Një person i shëndetshëm mendërisht mund të zgjidhë konfliktet e veta të brendshme dhe të jashtme përmes neutralizimit të mbrojtjeve dhe zhvillimit të një Superego-je më pak kufizuese. Funksioni përshtatës dhe vendosja e individit në marrëdhënie të ngushtë me njerëzit e tjerë dhe natyrën janë variablet më kritikë në studimin e individëve, që kalojnë në gjendjet e traumës psikike pasi organizimi i tyre i personalitetit ndikon përmbajtjen simptomatike të vetë traumës. Nëse i referohemi këtu teorisë së ekzistencializmit (10) mbi qenien, pjesa më e madhe e individëve dhe pacientëve (ne) nuk janë vetëvetja kur përftohen në botën e punës së përditshme dhe shoqëri (Mutein)dhe nuk bëhemi "vetja jonë" as në frikën e vetë-shkatërrimit nga pandemia. "Të gjithë janë tjetri dhe asnjë nuk është vetja. Das Man, që na siguron përgjigjen e pyetjes e "cilit” nga Dasein i jetës së përditshme është "askushi”, ndaj të cilit çdo Dasein ka dorëzuar veten në të qenurit-përreth-njëri-tjetrit” ( fq.128).

Për një kuptim më të qartë të Çrregullimit të Stresit Pandemik, që ne propozojmë në këtë artikull, le t'i referohemi qasjes psikanalitike. Në teorinë klasike të psikanalizës së Zigmund Frojd, psikopatologjia e jetës së përditshme është e lidhur padijshmërisht me mekazimat mbrojtës të vetes (Egos) si formimi i reagimit, zëvendësimi dhe identifikimi(11). Andaj,sipas tij, identifikimi është mjeti me të cilin individi-pacient jo vetëm kujton por, pjesërisht, zëvendëson emocionalisht humbjen e objektit të jashtëm në strukturën e vetes, pasi humbja “është një ndarje e transformuar...mes veprimtarive kritike të egos dhe vetes të ndryshuara nga identifikimi”. Një lidhje e jashtme mes nesh si njerëz zëvendësohet kësisoj nga nje tjetër lidhje e brendshme (p.sh. media sociale) që përfshin një lidhje të aspekteve aktive të personit 
ROLI I SHËRBIMIT PSIKOLOGJIK NË MENAXHIMIN E ÇRREGULLIMIT TË STRESIT PANDEMIK DHE RUAJTJEN E MIRËQENIES EMOCIONALE GJATË PERIUDHËS SË COVID-19.

si rezultat i egos të ndarë. Zhvillimi i egos ndodh në stade të ndryshme të ndërgjegjes ndaj objekteve, që në këtë rast përfaqëson të gjithë marrëdhënien njerëzore.

Krijimi individual i strukturave të sigurta të vetes përfshin ndarjen e egos nga vetja dhe represionin e asaj pjese, që shpërbëhet nga e tëra. Andaj, përvoja e sëmundjes që pritet të vijë, integrohet brenda vetes së pacientit dhe mund të shfaqet përmes kujtesës ose ndryshimin gradual të tërësisë së vetes në kohë.Mund të flasim kësisoj për një Çrregullim të Stresit Pandemik ndaj frikës së vazhduar, se do të na kapë sëmundja dhe procesit të vdekjes (traumë e vazhdueshme). Mund ta shohim këtë dinamikë të qartë në rastin e Italisë,ku frekuenca e postimit të videove dhe memeve mediatike në lidhje me sloganin "gjithçka do të shkojë mirë” që përpos një kumpti që shpreh pritshmëritë pozitive të të gjithëve, është edhe një pohim vetë-përfaqësimi për individin e sigurtë dhe të fortë. Ky kumpt është po kështu edhe një formë e transaksionit psikik të të qenurit "fëmijë"dhe "prind"në të njëjtin vend dhe kohë, andaj një lojë që luajmë me veten tonë mendore.

Sipas autorit psikanalist (12) mënyra e e identifikimit psikik të individit-pacient në pandemi mund të përshkruhet si:

1) modifikim të pjesshëm të konceptit total të vetes nën ndikimin e përfaqësimeve të reja mendore,

2)një nivel integrimi si të përfaqësimeve të vetes dhe objektit në një funksionim autonom të funksionimit të Egos në formën e tipareve të karakterit;

3) nivel të ri-organizimit të modeleve sjellore të individit-pacient nën ndikimin e strukturave të reja identifikuese. Në këtë rast, procesi i përfaqësimit të brendshëm përcaktohet në lidhje me ngjarjet stresante të perceptimit të individit-pacient mbi sëmundjen dhe vetë-shkatërrimin, që reflektojnë Traumën-ndaj-Vetes. Personaliteti i çrregullimit traumatik, sipas autorëve, reflekton disa tipologji unike (prototipe) të menaxhimit me ekuilibrat e marrëdhënies me të tjerët dhe vetes,që variojnë nga "funksion i personalitetit normal" në "personalitet me aspekte të plota simptomatike dhe nivele të çrregullimeve të personalitetit" $(13 ; 14)$.

Trauma përfaqëson çdo formë eksperience të rrethanave jetësore, që shpien individët të besojnë që një qëllim i rëndësishëm, qoftë instiktiv o i egos, duhet të sakrifikohet për të shmangur rreziqet ndaj të tjerëve ose të vetes. Le të imagjinojmë tani sesi koncepti eksistencialist i Dasein ndikon në formimin e çrregullimit traumatik (pandemik) dhe sesi kjo e fundit ndikon qenien (Dasein-in) nga ana e saj. Hapësira është qenia dhe koha jonë në 
Elisabeta Kafia, Silva Ibrahimi

izolim, ku ne jetojmë vazhdimisht (pa e "parë”fundin konkret). Nëse qenia jonë do të ndalonte në pozicionin $X$ të karantinës, duke qenë i vetëdijshëm për këtë pozicion, mund të thuhet se jemi në të njëjtën linjë me hapësirën dhe kohën. Nëse qenia jonë, do të ndalonte në një pozicion X, që mund të jetë me shumë siguri rasti i gjyshërve tanë a i të moshuarve, nëse ata do të duhet të qendrojnë të mbyllur për një kohë të pakufizuar ata mund ta perceptojnë veten (me ose pa vetëdije )sikur janë në pozicionin $X_{1}$, pra jo në një linjë me konceptin normal të kohës dhe hapësirës. Të qenurit në pozicionin X, teksa një subjekt mendon dhe sillet sikur të ishte në pozicionin $\mathrm{X}_{1}$, krijon traumën e lidhur me identitetin. Vendosja e qenies "sime" me qenien e "tjetrit" , që është në këtë rast jo në linjë me hapësirën dhe kohën, zhvillon struktura të distancimit në mendim dhe sjellje. Andaj, qenia në pozicionin $\mathrm{X}_{1}$, mund të konsiderohet si një çrregullsi e të menduarit dhe sjelljes ose si një Dasein traumatik. Kërkime të mëtejshme janë të nevojshme në këtë kontekst, jo vetëm për të ruajtur integritetin fizik të këtyre grup popullatave por edhe shëndetin e tyre mendor e fizik. Ne mendojmë se është shumë e rëndësishme pasja e një plani gjithëpërfshirës (bio-psikosocial)të mirëqenies për mbështetjen dhe ndihmën e individëve pas përfundimit material të pandemisë. Izolimi total i një individi të vetëm mund të jetë po aq i rrezikshëm sa edhe i të gjithë shoqërisë nëse nuk ndërmerren masa për shëndetin e tyre mendor. Të gjitha përpjekjet e masave të izolimit dhe lockdoën do të jenë të padobishme nëse do të kemi një numër të madh personash që do të shfaqin komorbiditete të simptomave depresive me ato të çrregullimit të stresit traumatik. Ndjesitë e të qenurit i pavlerë, i pashpresë,me vetë-vlerësim të ulët dhe madje edhe me ide të vetëvrasjes dhe tentativa për vetëvrasje mund të rriten në mënyrë dramatike te kjo grup-popullatë. Andaj,ne sugjerojmë që të trajtojmë shëndetin psikik dhe jo atë social si masë parandaluese. Përpos grup popullatave target edhe individët me probleme të shëndetit mendor mund të krijojnë një çrregullim të stresit traumatik sekondar, që mund të përkeqësojë mekanizmat e tyre të përballjes me stresin dhe traumën. Këto target-grupe mund të infektojnë edhe të tjerët që jetojnë me ta ose përreth tyre duke e forcuar më tej zinxhirin e traumës në një çrregullim të dyfishtë psikogjen, d.m.th.traumë të dyfishtë. Eksistenca në situatën e koronavirusit ose të çfarëdo situate tjetër të ngjashme është një "qendrim përtej mundësive të vetes". Ekzistencializmi e konsideron "esencën e qenies ndaj të qenurit"si të drejtuar nga e ardhmja ( sisch vorweg në termat e tij) projektuar dhe kuptuar në mundësitë e të qenurit. Esenca e Dassein mbretëron në ekzistencën e vet. Bota që ne kemi jetuar deri më tani ka qenë e lidhur me një nivel të caktuar konformiteti. Në thelb, çdo gjë që ne mendojmë, besojmë dhe themi sot ka qenë menduar, thënë dhe besuar më parë. Veprimtaritë që ne i argumentojmë si të vlefshme në kohën tonë(si për shembull mësimnxënia, puna dhe loja) vlerat dhe kuptimet që ne u atribuojmë atyre 
ROLI I SHËRBIMIT PSIKOLOGJIK NË MENAXHIMIN E ÇRREGULLIMIT TË STRESIT PANDEMIK DHE RUAJTJEN E MIRËQENIES EMOCIONALE GJATË PERIUDHËS SË COVID-19.

(suksesi, arritja dhe dashuria) si dhe stilet e veçanta përmes të cilave i arrijmë këto qëllime na janë dhënë nga kultura ku ne jetojmë.

\section{Përfundime}

Format e ndryshme të psikopatologjisë nuk janë entitete statistike të shkaktuara nga mangësitë e zhvillimit por kostelacione dinamike të konflikteve dhe mbrojtjeve që kanë për qëllim ruajtjen e ekuilibrit(geshtaltit)mes marrëdhënies dhe vetë-përcaktimit në marrëdhënie. Autonomia e zgjedhjes së lirë,pritshmëritë dhe forcat sociale krijojnë një personalitet të orjentuar ndaj qëllimeve sociale dhe psikike. Kur nuk ekziston liria për të qenë,vjen një izolim jo vetëm në termat materiale por edhe në organizimin e personalitetit dhe individit të brendësuar si entitet i veçant pa një gjendje specifike. Kemi të bëjmë këtu me një tendencë jo-materiale për të ndryshuar kufijtë e Thanatos(impulsit të vdekjes)pa pasjen e impulsi konkret. Andaj, shkatërrimi objektual dhe dëshira për vetë-shkatërrim është qartazi pika e fillimit të vetes që nuk mbërrin në destinacion. Izolimi dhe mbajtja e distancës fizike mund të parandalojë shpërhapjen e virusit në termat materiale të shpëtimit të jetëve por ne kemi nevojë për lidhjen sociale që të përballojmë emocionalisht stresin e shkaktuar nga pandemia. Në kontekstin e sotëm të Covid-19,të qenurit pa tjetrin e rëndësishëm mund të shpjerë në një personalitet të vetë-kufizuar që nga ana e vet krijon një traumë sociale dhe prototip traumatik, pra të pandemisë. Çdo gjendje e të qenurit në traumë zhvillon qartësisht një tjetër që përforcon të parën dhe duke u akumuluar në vazhdën e stresorit të sotëm pandemik krijon gjendjen traumatike të së nesërmes-Traumën e Madhe! Andaj, parandalimi në kohë i shëndetit mendor është gjithnjë më mirë sesa kurimi!

\section{Referenca}

1. Gecas, V.and Burke, P.J. (1995) Self and Identity. In Comparing psychological and sociological approaches to identity: identity status, identity capital and the individualization process, Cote' E. James dhe Schëartz J. Seith, Journal of Adolescence 25, pp.572-586

2. Marcia, J.E. (1966) Development and validation of ego identity status. Journal of Personality and Social Psychology,5,pp.551-558

3. Ezekiel J. Emanuel, Govind Persad et al. (2020) Fair Allocation of Scarce Medical Resources in the Time of Covid-19, The Neë England Journal of Medicine 
Elisabeta Kafia, Silva Ibrahimi

4. Biddison LD, Berkoëitz KA, Courtney B, et al. (2014) Ethical considerations: care of the critically ill and injured during pandemics and disasters: CHEST consensus statement. Chest; 146:4 Supplement: 145-155.

5. Rosenbaum SJ, Bayer R, Bernheim RG, et al. (2011) Ethical considerations for decision making regarding allocation of mechanical ventilators during a severe influenza pandemic or other public health emergency. Atlanta: Centers for Disease Control and Prevention.

6. Zucker H, Adler K, Berens D, et al. (2015) Ventilator allocation guidelines. Albany: Neë York State Department of Health Task Force on Life and the Laë

7. Wu Z, McGoogan JM. (2020) Characteristics of and important lessons from the coronavirus disease 2019 (COVID-19) outbreak in China: summary of a report of 72314 cases from the Chinese Center for Disease Control and Prevention. JAMA

8. Heidegger, M. (1976) Essere e Tempo.11 $1^{\text {th }}$ Edition, pp.27, pp.42, pp.128, pp.182 Pietro Chiodi ed) Longanesi \& C., Milano

9. Freud, S. (1957) Mourning and melancholia. Found in J. Strachey (Ed.), The standard edition of the complete psychological ëorks of Sigmund Freud (Vol. 14, pp. 237-258). London: Hogarth Press (First edition in 1917) Neë York: Basic Books

10. Kernberg, O. F. (1996) A psychoanalytic theory of personality disorders. Found in J. F. Clarkin \& M. F.

11. Blatt, S. J.and Shichman, S.(1983) Tëo primary configurations of psychopathology. Psychoanalysis and C ontemporary Thought, 6, pp.187-254

12. McWilliams, N. (2011). The Psychodynamic Diagnostic Manual: An effort to compensate for the Limitations of descriptive psychiatric diagnosis. Journal of Personality Assessment, 93(2), pp.112-122.

13. Qirjako E. (2011) Traumat, Pasojat, Trajtimi (Traumas, Consequences, Treatment), UFO Press

14. Ibrahimi, S.; Ostreni Halili, V. Gordon, M. Robert and Malaj, V. (2020) The psychodynamic prototype of leadership styles through the Personality Organization Chart: A neo prospects of Q-sort, Psychopen Germany (për shtyp) 